\title{
Bloom's Taxonomy and It's Application in USIM's iNaQ Model
}

\author{
Mahyuddin Hashim, Noornajihan Jaafar, Nurul Asiah Fasehah Muhammad, Adnan Mohamed \\ Yusof, Norakyairee Mohd. Raus, Ahmad Sanusi Azmi
}

\begin{abstract}
The integration of religious sciences (Naqli) with social and physical sciences (Aqli) manifests the uniqueness of education system in Universiti Sains Islam Malaysia (USIM). This model of teaching and learning, known as iNaQ, is however is still incomplete, thus leaving rooms for improvisation. The aspect of a standardised measurement and method of evaluation have become one of the vital impediment that ought to be enhanced. Thus, this study aims to improve the iNaQ model by applying and integrating Bloom's taxonomy of learning that will establish and produce a domain-based learning outcome. The present research utilises a qualitative approach in which textual analysis is applied as the main instruments of examination. The samples used are extracted from related documents. As a result, the application of Bloom's learning taxonomy in USIM's iNaQ Model creates clear learning outcomes for each levels of process. This finding provides a solution to the non-uniformity in the implementation and evaluation of courses in USIM due to the lack of clear iNaQ learning outcomes.
\end{abstract}

Index Terms: Aqli, Naqli, Integration of Knowledge, USIM, iNaQ

\section{INTRODUCTION}

The concept of Naqli and Aqli Knowledge Integration (iNaQ) is the manifestation of Universiti Sains Islam Malaysia (USIM)'s philosophy, which is the integration of Naqli and Aqli knowledge combined with noble qualities are the thrust in nurturing a noble generation and a knowledgeable society. The concept of integrating religious knowledge in various sciences has already been adopted in early Islam. (Azmi, 2017; 2018.) This is further reinforced by USIM's vision which is to integrate Naqli and Aqli knowledge to transform and create value to the country, ummah and humanity (Universiti Sains Islam Malaysia, 2015). USIM as the leader in iNaQ has succeeded in gaining the attention of interested parties from inside and outside the country to share their experience and guidelines in implementing this model (MK Nizam et al., 2015). Nevertheless, up until today, the existing $\mathrm{iNaQ}$ model is still incomplete from the aspect of a standardised measurement and evaluation method due to an

Revised Manuscript Received on September 22, 2019.

Mahyuddin Hashim, Faculty of Quranic and Sunnah Studies, Universiti Sains Islam Malaysia, Bandar Baru Nilai, Malaysia.

Noornajihan Ja'afar, Faculty of Quranic and Sunnah Studies, Universiti Sains Islam Malaysia, Bandar Baru Nilai, Malaysia.

Nurul Asiah Fasehah Muhammad, Faculty of Quranic and Sunnah Studies, Universiti Sains Islam Malaysia, Bandar Baru Nilai, Malaysia.

Adnan Mohamed Yusof, Faculty of Quranic and Sunnah Studies, Universiti Sains Islam Malaysia, Bandar Baru Nilai, Malaysia.

Norakyairee Mohd. Raus, Faculty of Quranic and Sunnah Studies, Universiti Sains Islam Malaysia, Bandar Baru Nilai, Malaysia.

Ahmad Sanusi Azmi, Faculty of Quranic and Sunnah Studies, Universiti Sains Islam Malaysia, Bandar Baru Nilai, Malaysia. unclear iNaQ learning outcome. This results in the non-uniformity in the implementation aspects of teaching and learning (Adnan, 2015 \& MK Nizam et al., 2015).

Hence, USIM faces difficulty in coordinating the implementation of the INaQ model in the courses offered due to the unclear learning outcomes (Adnan, 2015). The creation of a standardised model that is acceptable by all courses offered at USIM becomes an urgent need. This is in line with USIM's aspirations to become the regional centre of reference in iNaQ globally by the year 2025 (Musa, 2015). This study will apply Bloom's taxonomy of learning in the $\mathrm{iNaQ}$ model as it is adopted in the nation's mainstream higher education that comes with a domain-based learning outcome. A similar study was conducted by Najwa, et al. (2016) that investigates the equivalence of the iNaQ model with Bloom's taxonomy. Nevertheless, the study was theoretical and did not result in a clear iNaQ learning outcome. Hence, this study will identify the application of Bloom's taxonomy of learning in USIM's iNaQ model.

\section{A. USIM'S iNaQ Model}

USIM's iNaQ model is based on four levels of process called mustawa (Bhasah et al., 2015).

1) Mustawa $1(\mathrm{M1})-\mathrm{Ta}$ 'sil (Ayatisation)

This refers to use of the main sources of Islamic teachings as a reference including the al-Quran, Hadith, and venerable heritage manuscripts by Islamic scholars. At this level, a particular concept or theory in Aqli knowledge is matched and correlated with the relevant sources in Islam. On the other hand, Naqli knowledge is associated with the Aqli knowledge that is related such as scientific theory and philosophy. This matching is usually done in a direct manner and based on the text without epistemological and paradigmatic considerations of Naqli and Aqli knowledge. It acts as an opening towards furthering knowledge exploration in the subsequent level, although it needs to be conducted in a cautious and deliberate manner to avoid negative implications towards the Islamic source especially those that involves the theoretical and speculative aspects which are non-factual.

2) Mustawa 2 (M2) - Muqaranah (Comparison)

This refers to the differences and similarity in approach between Naqli and Aqli knowledge that is formed when the association of a concept of science and its religious sources is examined in depth. This requires clear understanding, analysis and assessment, not only on the concept of science, but also on aspects related to the epistemology and the paradigms of Naqli and Aqli knowledge involved and its implications on the resulting concepts.

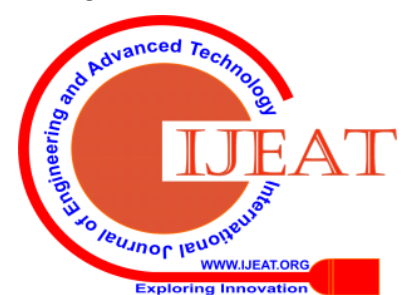


3) Mustawa 3 (M3) - Takyif (Adaptation)

At this stage, the process is implemented by selecting, filtering, evaluating, adapting and applying any principles, values and frameworks of science that are not contradictory to Islam in a scientific and equitable manner.

4) Mustawa 4 (M4) - Takamul (Integration)

At this stage the process of merging and application of various disciplines is done to produce a holistic discipline through the curriculum of study being offered. The curriculum needs to fulfil the needs of the current fields of science and industry, in line with the teachings of Islam and at the same time provide opportunities for the expansion and generation of knowledge based on a new paradigm of knowledge for the future.

This discussion is summarised per the following Figure 1.

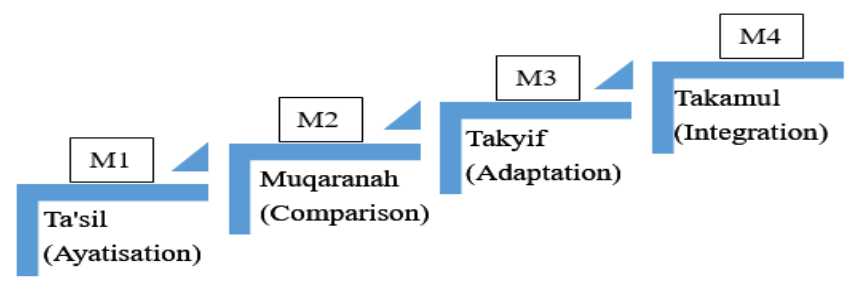

\section{B. Bloom's Taxonomy of Learning}

Bloom's taxonomy of learning is a set of learning categories that were classified by Bloom et al. (as cited in Kementerian Pengajian Tinggi, 2012). There are three learning domains, namely cognitive, psychomotor and affective domains.

1) Cognitive Domain: Learning in this domain cover learning that involves the mind, specifically intellectual skills.

2) Psychomotor Domain: Learning in this domain covers movement, coordination and physical skills. Development in this domain requires training and is usually measured in terms of speed, accuracy, distance, process or technique during execution.

3) Affective domain: Learning in this domain covers learning that involves emotions such as feelings, values, appreciation, enthusiasm, motivation and attitude.

For each domain, it is further classified into various levels according to complexity. This means that the sequence of levels in each domain is hierarchical as in Tables 2, 3 and 4.

Table 1. Levels and Description of Cognitive Domain (as cited in Kementerian Pengajian Tinggi, 2012)

\begin{tabular}{|l|l|}
\hline Levels & Description \\
\hline 1. Remembering & $\begin{array}{l}\text { Recall previous information that has been } \\
\text { learned. }\end{array}$ \\
\hline $\begin{array}{l}\text { Understanding } \\
\text { 3nderstand the meaning, translation, } \\
\text { interpolation, and interpretation of } \\
\text { instructions and problems. State the } \\
\text { problem by using one's own words. } \\
\text { Establish relationships between sates, } \\
\text { principles, generalisation or values. }\end{array}$ \\
\hline $\begin{array}{l}\text { 3ble to apply what has been learned to a } \\
\text { new situation. Facilitate the transfer of } \\
\text { knowledge to new or unique situations. }\end{array}$ \\
\hline
\end{tabular}

\begin{tabular}{|l|l|}
\hline 4. Analysing & $\begin{array}{l}\text { To dissect or examine the material or thing } \\
\text { that is learned to its components so that its } \\
\text { organizational structure can be understood, } \\
\text { thus distinguishing it from others. }\end{array}$ \\
\hline 5. Evaluating & $\begin{array}{l}\text { Make judgments about the value of an } \\
\text { idea/material/proposal/solution/action plan } \\
\text { etc., thereby justifying or supporting the } \\
\text { stand/decision/action taken/assessment or } \\
\text { criticisms made. }\end{array}$ \\
\hline 6. Creating & $\begin{array}{l}\text { Building structures or patterns from diverse } \\
\text { elements. Merging parts together to form } \\
\text { something complete, with an emphasis on } \\
\text { creating new meaning or new structure. }\end{array}$ \\
\hline
\end{tabular}

Table 2. Levels and Description of the Psychomotor Domain (as cited in Kementerian Pengajian Tinggi, 2012)

\begin{tabular}{|c|l|}
\hline \multicolumn{1}{|c|}{ Levels } & \multicolumn{1}{|c|}{ Description } \\
\hline 1. Perception & $\begin{array}{l}\text { The ability to use signals obtained through } \\
\text { senses (eyes, ears, nose, skin, tongue) to } \\
\text { guide motor activity, which are activities } \\
\text { involving the use of muscles. }\end{array}$ \\
\hline 2. Set & $\begin{array}{l}\text { Ready for action. This state can be in the } \\
\text { form of mental, physical or emotional } \\
\text { readiness. }\end{array}$ \\
\hline $\begin{array}{l}\text { 3. Guided } \\
\text { Response }\end{array}$ & $\begin{array}{l}\text { To be able to imitate a skill or execute it by } \\
\text { trial and error. It is the preliminary stage to } \\
\text { learn a complex skill. }\end{array}$ \\
\hline $\begin{array}{l}\text { 4. Mechanism } \\
\text { The acquired skills have become habit and } \\
\text { movements can be executed with some } \\
\text { confidence and proficiency. It is an } \\
\text { intermediate stage in learning a complex } \\
\text { skill. }\end{array}$ \\
\hline $\begin{array}{l}\text { 5. Complex } \\
\text { Response }\end{array}$ & $\begin{array}{l}\text { Skilled in performing skills involving } \\
\text { complex movements. }\end{array}$ \\
\hline 6. Adaptation & $\begin{array}{l}\text { The acquired skills have become excellent } \\
\text { and students are able to modify their } \\
\text { movement patterns according to specific } \\
\text { needs. }\end{array}$ \\
\hline 7. Origination & $\begin{array}{l}\text { To create new movements to meet a specific } \\
\text { situation or requirement. Learning at this } \\
\text { level emphasises creativity based on highly } \\
\text { developed skills. }\end{array}$ \\
\hline
\end{tabular}

Table 3. Level and Description of the Affective Domain (as cited in Kementerian Pengajian Tinggi, 2012)

\begin{tabular}{|c|l|}
\hline Levels & \multicolumn{1}{|c|}{ Description } \\
\hline 1. Receiving & $\begin{array}{l}\text { Demonstrates awareness of a cue, } \\
\text { phenomenon, object or behaviour. The } \\
\text { criteria for achievement of this level is to }\end{array}$ \\
& $\begin{array}{l}\text { only demonstrate conscious behaviour such } \\
\text { as listening, giving attention, or } \\
\text { identifying/naming/ choosing something. }\end{array}$ \\
\hline
\end{tabular}




\begin{tabular}{|l|l|}
\hline 2. Responding & $\begin{array}{l}\text { To not only to be aware of the existence } \\
\text { of a phenomenon, but also to respond to } \\
\text { it. }\end{array}$ \\
\hline 3. Valuing & $\begin{array}{l}\text { Giving value / showing appreciation to } \\
\text { a phenomenon, object or behaviour that } \\
\text { catches his/her attention or that is } \\
\text { experienced. }\end{array}$ \\
\hline 4. Organising & $\begin{array}{l}\text { The ability to rearrange values } \\
\text { according to priority by comparing the } \\
\text { difference between these values, resolve } \\
\text { conflicts between them, and } \\
\text { subsequently form a unique value } \\
\text { system. }\end{array}$ \\
\hline 5. Characterisation & $\begin{array}{l}\text { To have a solid system of values that } \\
\text { controls their behaviour. This behaviour } \\
\text { will be demonstrated consistently, } \\
\text { predictably and more importantly will } \\
\text { be part of the student's character. }\end{array}$ \\
\hline
\end{tabular}

\section{METHODOLOGY}

The present study is both analytical and comparative in nature. To critically analyse, this study utilises a qualitative approach, which applies document analysis methods (Thompson, 2002). The samples used are the Integrasi Ilmu Naqli Aqli; Perspektif Fakulti Pengajian Quran dan Sunnah (Integration of Naqli and Aqli Knowledge; Perspective of Faculty of Quran and Sunnah Studies) (Bhasah et al., 2015) and Bloom's taxonomy in Asas Pembelajaran dan Pengajaran Pensyarah Institusi Pengajian Tinggi (The Basics of Learning and Teaching of Lecturers of Higher Education Institutions) (Kementerian Pengajian Tinggi, 2012).

The first sample is a collection of writings that discuss the application and implementation of the science of Naqli and Aqli knowledge conducted by the Faculty of Major Language Studies, USIM. This book was selected as a sample study to understand the USIM iNaQ model and its implementation requirements. The second sample is a module for reference and guidance in providing comprehensive training schemes for academic instructors at institutions of higher education (IPT). This book was chosen to analyse the learning outcome of Bloom's Taxonomy at IPT. To ensure the validity of the data findings, this study had undergone an expert review process by four experts in this field that have evaluated and concurred the study findings.

\section{RESULTS AND DISCUSSION}

The application of Bloom's Taxonomy of Learning in USIM's iNaQ model is described in Table 5.
Table 5: The application of Bloom's Learning Domains in mustawa Ta'sil

\begin{tabular}{|c|c|c|}
\hline Mustawa & \begin{tabular}{|c} 
Levels of Bloom's \\
Learning \\
Domains
\end{tabular} & Learning Outcome \\
\hline \multirow[t]{3}{*}{$\begin{array}{l}\text { Ta'sil } \\
\text { (Ayatisation) }\end{array}$} & $\begin{array}{l}\text { 1. Remembering } \\
\text { (Cognitive) }\end{array}$ & $\begin{array}{l}\text { Students can match } \\
\text { Naqli knowledge with } \\
\text { Aqli knowledge and can } \\
\text { only recall the match } \\
\text { without being able to } \\
\text { provide any further } \\
\text { explanation, and vice } \\
\text { versa. } \\
\text { For example: Students } \\
\text { can match between } \\
\text { ear-related scientific } \\
\text { studies with verse } 12 \text { of } \\
\text { Surah al-Kahfi and can } \\
\text { only recall the match } \\
\text { without being able to } \\
\text { provide any further } \\
\text { explanation and vice } \\
\text { versa. }\end{array}$ \\
\hline & $\begin{array}{l}\text { 2. Understanding } \\
\text { (Cognitive) }\end{array}$ & $\begin{array}{l}\text { Students can match } \\
\text { Naqli knowledge with } \\
\text { Aqli knowledge and able } \\
\text { to explain or describe } \\
\text { the match using his/her } \\
\text { own words. } \\
\text { For example, students } \\
\text { can match ear-related } \\
\text { scientific studies with } \\
\text { Quranic verses and able } \\
\text { to explain using his/her } \\
\text { own words. }\end{array}$ \\
\hline & $\begin{array}{l}\text { 3. Perception } \\
\text { (Psychomotor) }\end{array}$ & $\begin{array}{l}\text { Students can utilize } \\
\text { information from their } \\
\text { five senses to guide } \\
\text { activities involving the } \\
\text { use of the muscles to } \\
\text { correlate between Naqli } \\
\text { and Aqli knowledge. } \\
\text { For Example: Students } \\
\text { can detect non-verbal } \\
\text { cues and assess the } \\
\text { appropriateness of } \\
\text { eating with their bare } \\
\text { right hand versus dining } \\
\text { in formal Western style } \\
\text { using cutlery. }\end{array}$ \\
\hline
\end{tabular}




\begin{tabular}{|l|l|l|}
\hline $\begin{array}{l}\text { 4. Receiving } \\
\text { (Affzective) }\end{array}$ & $\begin{array}{l}\text { Students demonstrate } \\
\text { the awareness to } \\
\text { match between Naqli } \\
\text { and Aqli knowledge. } \\
\text { For example: Students } \\
\text { listen to the Qur'anic } \\
\text { verses relating to } \\
\text { Mecca as the centre of } \\
\text { thearth from the } \\
\text { lecturers. }\end{array}$ \\
\hline
\end{tabular}

Table 6: The application of Bloom's learning domains in mustawa Muqaranah.

\begin{tabular}{|c|c|c|}
\hline Mustawa & $\begin{array}{l}\text { Levels of Bloom's } \\
\text { Learning Domains }\end{array}$ & Learning Outcome \\
\hline \multirow[t]{3}{*}{$\begin{array}{l}\text { Muqaranah } \\
\text { (Comparison) }\end{array}$} & $\begin{array}{l}\text { 1.Applying } \\
\text { (Cognitive) }\end{array}$ & $\begin{array}{l}\text { Students can compare } \\
\text { Naqli knowledge with } \\
\text { Aqli knowledge and } \\
\text { able to apply the } \\
\text { comparison to new } \\
\text { situations. } \\
\text { For example, students } \\
\text { can compare } \\
\text { ear-related scientific } \\
\text { studies with Quranic } \\
\text { verses and able to } \\
\text { apply the comparison } \\
\text { to other scientific } \\
\text { studies with Quranic } \\
\text { verses. }\end{array}$ \\
\hline & $\begin{array}{l}\text { 2. Analysing } \\
\text { (Cognitive) }\end{array}$ & $\begin{array}{l}\text { Students can examine } \\
\text { Islamic knowledge and } \\
\text { further differentiate } \\
\text { or } \\
\text { similarities } \\
\text { non-Islamic } \\
\text { knowledge. } \\
\text { For example: Students } \\
\text { can examine and } \\
\text { differentiate Islamic } \\
\text { economics and thus } \\
\text { distinguish them from } \\
\text { the capitalist economy. }\end{array}$ \\
\hline & $\begin{array}{l}\text { 3. Set } \\
\text { (Psychomotor) }\end{array}$ & 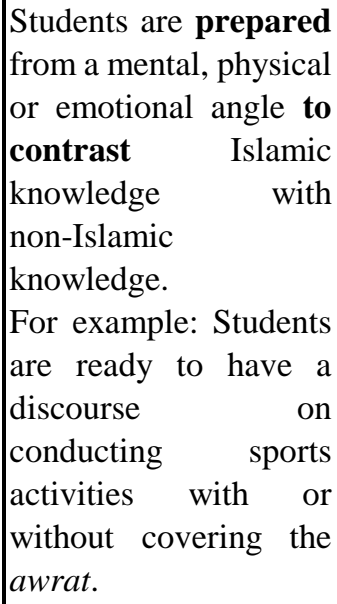 \\
\hline
\end{tabular}

\begin{tabular}{|c|c|}
\hline $\begin{array}{l}\text { 4. Guided Response } \\
\text { (Psychomotor) }\end{array}$ & $\begin{array}{l}\text { Students can compare } \\
\text { Islamic knowledge and } \\
\text { non-Islamic knowledge } \\
\text { and implement it by } \\
\text { trial and error. } \\
\text { For example: Students } \\
\text { can perform sports } \\
\text { activities by covering } \\
\text { the awrat according to } \\
\text { the rules or as } \\
\text { demonstrated. }\end{array}$ \\
\hline $\begin{array}{l}\text { 5. Mechanism } \\
\text { (Psychomotor) }\end{array}$ & $\begin{array}{l}\text { Student can compare } \\
\text { skill in Islamic } \\
\text { knowledge and non } \\
\text { Islamic knowledge and } \\
\text { can implement the } \\
\text { islamic knowledge } \\
\text { with some confidence } \\
\text { and proficiency. } \\
\text { For example: Student } \\
\text { can compare perform } \\
\text { sports activities by } \\
\text { covering awrat and not } \\
\text { covering awrat and } \\
\text { cover their awrat when } \\
\text { perform the sports } \\
\text { activities with some } \\
\text { confidence and } \\
\text { proficiency. }\end{array}$ \\
\hline $\begin{array}{l}\text { 6. Complex Overt } \\
\text { Response } \\
\text { (Psychomotor) }\end{array}$ & $\begin{array}{l}\text { Students can compare } \\
\text { Islamic knowledge and } \\
\text { non-Islamic knowledge } \\
\text { and skilfully } \\
\text { implement the Islamic } \\
\text { knowledge. } \\
\text { For example: Student } \\
\text { can compare perform } \\
\text { sports activities by } \\
\text { covering awrat and not } \\
\text { covering awrat and can } \\
\text { skilfully cover their } \\
\text { awrat when perform } \\
\text { sports activities. }\end{array}$ \\
\hline
\end{tabular}




\begin{tabular}{|c|c|}
\hline $\begin{array}{l}\text { 7. Responding } \\
\text { (Affective) }\end{array}$ & $\begin{array}{l}\text { Students are not only } \\
\text { aware of the } \\
\text { comparison between } \\
\text { Islamic r and } \\
\text { non-Islamic science } \\
\text { but also to respond to } \\
\text { it. } \\
\text { For example: Students } \\
\text { engage in discussions, } \\
\text { presentations and ask } \\
\text { questions to compare } \\
\text { between the Islamic } \\
\text { economy and the } \\
\text { Capitalist economy. }\end{array}$ \\
\hline $\begin{array}{l}\text { 8. Valuing } \\
\text { (Psychomotor) }\end{array}$ & $\begin{array}{l}\text { Students show an } \\
\text { appreciation } \\
\text { comparing between } \\
\text { Naqli and } \\
\text { knowledge in aqli } \\
\text { phenomenon that has } \\
\text { gained his/her attention } \\
\text { or that is experienced. } \\
\text { Students } r \text { exhibit } \\
\text { sensitivity to the } \\
\text { differences between } \\
\text { the two types of } \\
\text { knowledge. } \\
\text { For example: Students } \\
\text { demonstrate r an } \\
\text { appreciation } \\
\text { comparing between the } \\
\text { Islamic economy and } \\
\text { the ryanitalist } \\
\text { economy. Students } \\
\text { exhibit sensitivity to } \\
\text { the differences } \\
\text { between both types of } \\
\text { economy. }\end{array}$ \\
\hline
\end{tabular}

Table 7: The application of Bloom's Learning Domains in mustawa Takyif.

\begin{tabular}{|l|l|l|}
\hline \multicolumn{1}{|c|}{ Mustawa } & $\begin{array}{c}\text { Levels of Bloom's } \\
\text { Learning Domains }\end{array}$ & \multicolumn{1}{|c|}{ Learning Outcome } \\
\hline Takyif & $\begin{array}{l}\text { 1. Evaluating } \\
\text { (Cognitive) }\end{array}$ & $\begin{array}{l}\text { Students are skilled in } \\
\text { making judgement } \\
\text { with regards to Western } \\
\text { Aqli knowledge, and } \\
\text { can justify and } \\
\text { support the stance } \\
\text { taken, and } \\
\text { subsequently able to } \\
\text { filter, adapt, and use } \\
\text { any principles, values } \\
\text { and framework that do } \\
\text { not conflict with Islam. } \\
\text { For example: Students } \\
\text { are skilled in making } \\
\text { judgement towards the } \\
\text { Western democracy }\end{array}$ \\
\hline
\end{tabular}

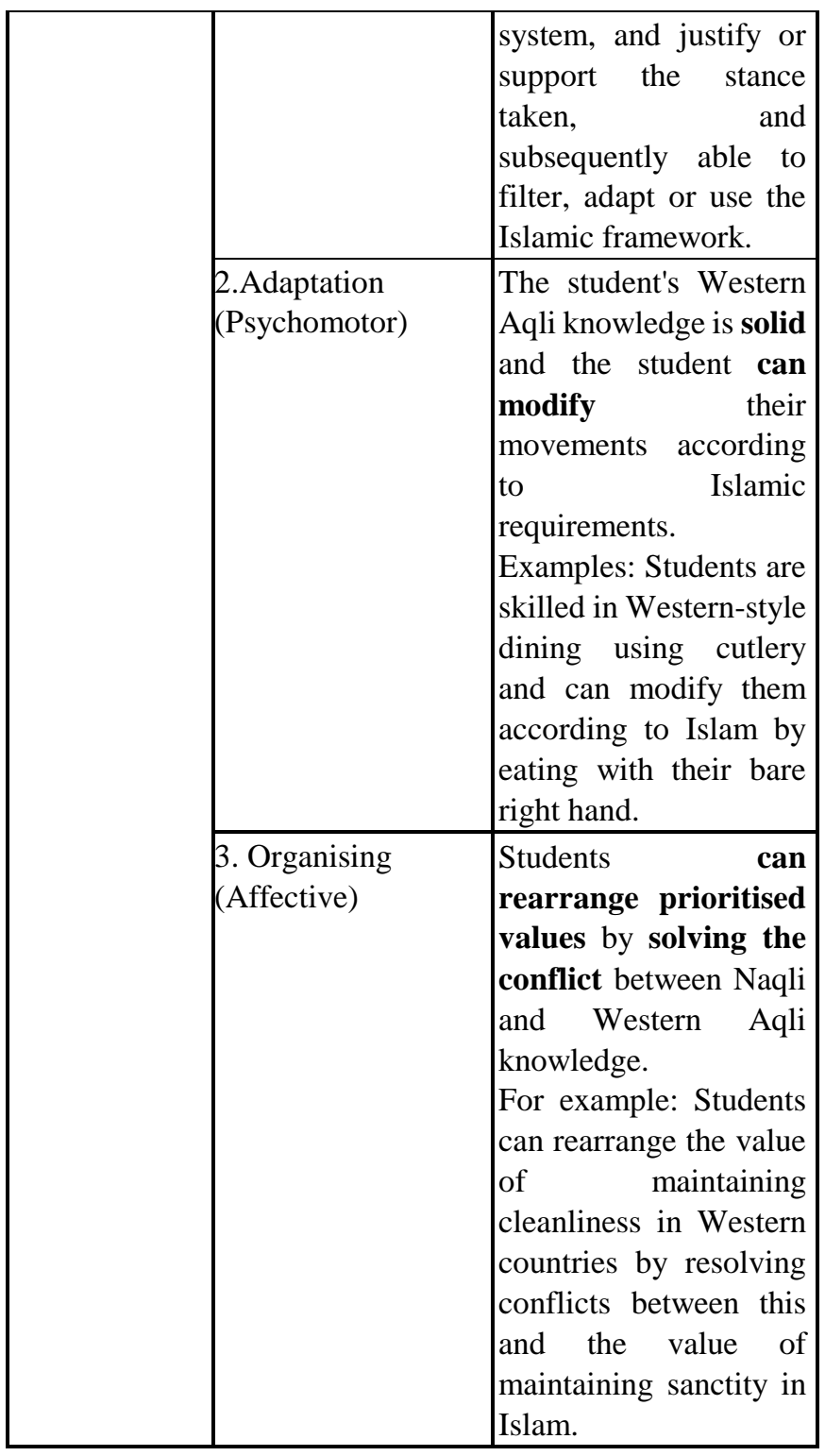

Table 8: The application of Bloom's Learning Domains in mustawa Takamul.

\begin{tabular}{|c|c|c|}
\hline Mustawa & \begin{tabular}{|l|} 
Levels of Bloom's \\
Learning Domains
\end{tabular} & Learning Outcome \\
\hline $\begin{array}{c}\text { Takamul } \\
\text { (Integration) }\end{array}$ & $\begin{array}{l}\text { 1. Creating } \\
\text { (Cognitive) }\end{array}$ & $\begin{array}{l}\text { Students can create a } \\
\text { new model/concept/ } \\
\text { theory/ knowledge as a } \\
\text { result of a } \\
\text { combination of Naqli } \\
\text { and Aqli knowledge. } \\
\text { For example: Students } \\
\text { successfully built an } \\
\text { Islamic model of } \\
\text { communication as a } \\
\text { result of combining } \\
\text { Naqli and Aqli } \\
\text { knowledge. }\end{array}$ \\
\hline
\end{tabular}




\begin{tabular}{|l|l|l|}
\hline 2. Origination & $\begin{array}{l}\text { Students can create } \\
\text { (Psychomotor) } \\
\text { newills to fulfil the } \\
\text { requirements of the } \\
\text { combining Naqli and } \\
\text { Aqli knowledge. } \\
\text { For example: Student } \\
\text { demonstrates the ability } \\
\text { to create Apps as a } \\
\text { result of combining } \\
\text { Naqli and Aqli } \\
\text { knowledge. }\end{array}$ \\
\hline $\begin{array}{l}\text { 3. Characterization } \\
\text { (Affective) }\end{array}$ & $\begin{array}{l}\text { Students can build } \\
\text { new models/concepts/ } \\
\text { theories/ knowledge } \\
\text { that have a solid value } \\
\text { system that controls } \\
\text { their behaviour. } \\
\text { Students have a noble } \\
\text { heart that becomes their } \\
\text { character. } \\
\text { For example: Students } \\
\text { can build a noble and } \\
\text { moral system that } \\
\text { becomes part of his/her } \\
\text { character based on the } \\
\text { character of the } \\
\text { Prophet S.A.W. }\end{array}$ \\
\hline
\end{tabular}

\section{CONCLUSION}

In conclusion, the findings of this study have implications to the implementation of $\mathrm{iNaQ}$ in teaching and learning in USIM, and to the leader at the national or even global level. This is in line with USIM's vision to integrate Naqli and Aqli knowledge to transform and create value to the country, ummah and humanity.

\section{ACKNOWLEDGMENT}

The authors gratefully acknowledge the help of the Universiti Sains Islam Malaysia in providing the USIM Research Grant (Project Code: PPP/USG-0116/FPQS/30/ 12516).

\section{REFERENCES}

1. Adnan, M. Y. 15 Tahun Mengemudi Integrasi Naqli dan Aqli. Bandar Baru Nilai: Penerbit USIM. 2015.

2. Azmi, Ahmad Sanusi. "Narratives of the Prophet's Early Life in Șaḥīh Al-Buhārī: An Analytical Study of Qur'ānic References in Sīra Nabawiyya." Al-Bayan: Journal of Qur'an and Hadith Studies 15.2 (2017): 193-212.

3. Azmi, Ahmad Sanusi. "The Development of Dalail Nubuwwa Literature: An Emblem of Interreligious Dialogue in Early Islam." The Social Sciences 13.5 (2018): 1072-1078.

4. Azmi, A. S., Ismail, M. Y., Ahmad, H., Nor, Z. M., \& Sobali, A. M. (2018). Statistical frequency of quranic references in the works of hadith: An analytical study of the narratives of the prophet's early life. International Journal of Civil Engineering and Technology, 9(5), 686-693.

5. Bhasah, A. B., M Najib, J., Zainur, R. A., Asmak, A. R., \& Zainal, A. H. Konsep Integrasi Naqli dan Aqli Menurut Perspektif Bahasa dan Pendidikan. In J. M Najib, Integrasi Naqli dan Aqli Dan Perlaksanaannya di Fakulti Pengajian Bahasa Utama, Bandar Baru Nilai: Penerbit USIM, 2015, (pp. 17-46).
6. Kementerian Pengajian Tinggi. Asas Pembelajaran dan Pengajaran Pensyarah Institusi Pengajian Tinggi, Johor: UHTM. 2012.

7. MK Nizam, Z. N., Shumsuddin, Y., Adnan, M. Y., \& Norhasnira, I. (2015). Integration of Knowledge from Quran Sunnah at The Cross Road Reality or Myth: An Overview. En M. K. Nizam, Integrasi Ilmu Naqli Aqli: Perspektif Fakulti Pengajian Quran dan Sunnah, USIM, Bandar Baru Nilai: Penerbit USIM, 2015, (pp. 27-52).

8. Musa, A. Amanat tahun 2015. Retrieved from Universiti Sains Islam Malaysia:http://www.usim.edu.my/info/latar-belakang/amanat-tahun-2 015, 2015.

9. Najwa, H. M., N Fathihin, M. N., Norasikin, F., Rozhan, M. I., Mu'azz, S., \& Nurhuda, R. Integrated Naqli \& Aqli Self-Instructional Learning Module Framework Design For USIM. International University Carnival on e-Learning (IUCEL2016), UTM. Skudai: Penerbit UTM, 2016.

10. Universiti Sains Islam Malaysia.. Motto, Philosophy, Vision \& Mission Retrieved from Universiti Sains Islam Malaysia: https://www.usim.edu.my/motto-philosophy-vision-mission/

\section{AUTHORS PROFILE}

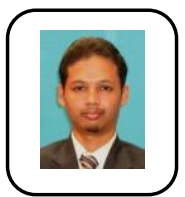

Mahyuddin Hashim has Ph.D qualification from Universiti Sains Islam Malaysia. He works as senior lecturer at Faculty of Quranic and Sunnah Studies, Universiti Sains Islam Malaysia. $\mathrm{He}$ is specialized in Quranic Studies. He has 18 research in his area of specialization.

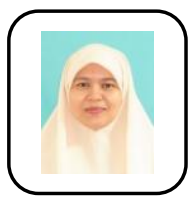

Noornajihan Ja'afar has $\mathrm{Ph} . \mathrm{D}$ qualification from Universiti Kebangsaan Malaysia. She works as senior lecturer at Faculty of Quranic and Sunnah Studies, Universiti Sains Islam Malaysia. She is specialized in Islamic Education. She has 31 research in her area of specialization.

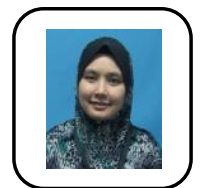

Nurul Asiah Fasehah Muhammad has Ph.D qualification from Universiti Kebangsaan Malaysia. She works as senior lecturer at Faculty of Quranic and Sunnah Studies, Universiti Sains Islam Malaysia. She is specialized in Islamic Education. She has 19 research in her area of specialization.

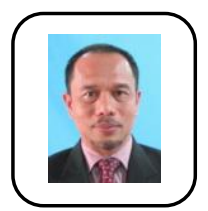

Adnan Mohamed Yusof has Ph.D qualification from Universiti Kebangsaan Malaysia. He works as Associate Professor at Faculty of Quranic and Sunnah Studies, Universiti Sains Islam Malaysia. He is specialized in Quranic Studies. He has 38 research in his area of specialization.

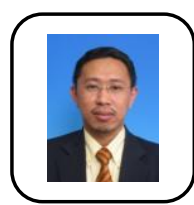

Norakyairee Mohd. Raus has Ph.D qualification from Universiti Islam Antarabangsa Malaysia. He works as senior lecturer at Faculty of Quranic and Sunnah Studies, Universiti Sains Islam Malaysia. $\mathrm{He}$ is specialized in Education of Special Needs. He has 24 research in his area of specialization.

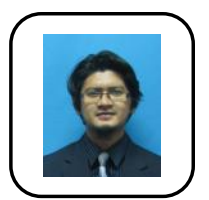

Ahmad Sanusi Azmi has Ph.D qualification from University Of Birmingham, United Kingdom. He works as senior lecturer at Faculty of Quranic and Sunnah Studies, Universiti Sains Islam Malaysia. $\mathrm{He}$ is specialized in Hadis Studies. He has 13 research in his area of specialization. 